\title{
Editorial: Alternatives to Antimicrobial Growth Promoters and Their Impact in Gut Microbiota, Health and Disease
}

\author{
Guillermo Tellez* and Juan D. Latorre \\ Department of Poultry Science, University of Arkansas Fayetteville, Fayetteville, AR, United States
}

Keywords: probiotics, prebiotics, phytoadditives, vector vaccine, intestinal health, animal production

Editorial on the Research Topic

Alternatives to Antimicrobial Growth Promoters and Their Impact in Gut Microbiota, Health and Disease

It has been estimated that foodborne infections in the USA cause over 76 million illnesses responsible for 5,000 fatalities each year (1). In addition, the annual economic loss attributed to the four most common enteropathogens (Salmonella spp., Campylobacter spp., E. coli, and Shigella spp.)

OPEN ACCESS

Edited by:

Michael Kogut,

Agricultural Research Service (USDA), United States

Reviewed by: Raghavendra G. Amachawadi, Kansas State University, United States

*Correspondence: Guillermo Tellez gtellez@uark.edu

Specialty section: This article was submitted to Veterinary Infectious Diseases, a section of the journal Frontiers in Veterinary Science

Received: 10 August 2017 Accepted: 31 October 2017 Published: 10 November 2017

Citation:

Tellez G and Latorre JD (2017) Editorial: Alternatives to Antimicrobial

Growth Promoters and Their Impact in Gut Microbiota,

Health and Disease.

Front. Vet. Sci. 4:196. doi: 10.3389/fvets.2017.00196 has been estimated to reach $\$ 7$ billion dollars (2). Hence, elimination of these pathogens from animal products has become a priority due to the increased numbers of human foodborne cases and governmental regulations (3). As a result, several methods to control foodborne pathogens have been implemented, including the use of antibiotics. Nevertheless, history has confirmed that the widespread use of even new antibiotics is ultimately followed, by the appearance of resistance to those drugs, creating issues at a global scale. In recent years, substantial scientific evidence has shown that the use of certain antibiotics increases enteric colonization of antibiotic-resistant strains of enteric pathogens not only in humans but also in domestic animals $(4,5)$. Some of these pathogens have been shown to be extremely resistant to all antibiotics commonly used, or are capable of rapidly develop resistance when exposed to antibiotic prophylaxis or treatment. As a result, an increase in the rate and severity of these infections in food-producing animals as well as in humans has been reported in many countries around the world (6-9). Antibiotics are ineffective in the treatment of multidrug resistant bacteria. Equally frighteningly, is the fact that indiscriminate use of antibiotics can actually induce disruption of the intestinal microbiome $(10,11)$, reducing the production of short chain fatty acids (12) and increasing luminal $\mathrm{pH}$ in the distal gastrointestinal tract (13). Therefore, we must reconsider the negative consequences that disruption of the microbiome has in the biology of metazoans (dysbacteriosis). A common inclination is to classify all bacteria as "harmful" entities. Nothing could be further from the truth. The number of valuable bacterial species far exceeds the number of pathogenic species and are, in reality, essential for life. After millions of years of evolution, prokaryotes established diverse interactions with eukaryotes (14) and then life on earth change. These cooperative interactions between kingdoms (mutualism) have a fundamental role in the generation and conservation of life $(15,16)$. One example is the gut microbiome, estimated to contain 500-1,000 different bacterial species and clearly outnumbering the total number of genes and cells of the host by an estimated of 10-fold (17). Collectively, the intestinal microbiome represents a "forgotten organ," responsible for orchestrating major physiological tasks. Contrast with control animals, gnotobiotic animals have numerous host functions affected by the lack of intestinal microbiome, therefore affecting their immune, endocrine, nervous, and digestive systems (18-22). In simple words, both animal 
and plant life depend on the mutualism relationships with their related cousins, prokaryotes. And yet, the fragile composition of the microbiome is influenced by many factors such as mode of delivery, age, dietary nutrient composition, infections, inflammation, stress, and of course, medication $(23,24)$. It is, therefore, not surprising to see that as a result of the indiscriminate use and abuse of antibiotics, the incidence of some foodborne pathogens such as Salmonella and Campylobacter are increasing worldwide, with reports of antibiotic resistance in clinical isolates of these and other enteric pathogens (25-27). Consequently, the World Health Organization (WHO) published a list of antibiotics that should be reserved for human use only (28). Interestingly, soon after the publication of the WHO report, and with growing consumer and scientific pressures, the European Union went one step further, creating new legislations banning the use of all antibiotics as growth promoters as of January 2006 (29-31). However, in some countries, the indiscriminate use and misuse of antibiotics are still a sad reality, particularly where there is no legislation regulating the use of antibiotic in animal agriculture. Particularly in those countries, is remarkable to confirm the alarming incidence of certain enteric pathogens associated with the indiscriminate use of some antibiotics by food-producing companies (10, 32-34). Antibiotics should be limited to infections of specific bacteria with known antibiotic sensitivity.

Over a century ago, Metchnikoff (35) proposed the revolutionary idea to consume viable bacteria to promote health by

\section{REFERENCES}

1. Allos BM, Moore MR, Griffin PM, Tauxe RV. Surveillance for sporadic foodborne disease in the 21st century: the FoodNet perspective. Clin Infect Dis (2004) 38(Suppl 3):S115-20. doi:10.1086/381577

2. ArcherDL, KvenbergJE. Incidence and cost of foodborne diarrhealdiseasein the United States. J Food Prot (1985) 48:887-94. doi:10.4315/0362-028X-48.10.887

3. Mead PS, Slutsker L, Dietz V, McCaig LF, Bresee JS, Shapiro C, et al. Foodrelated illness and death in the United States. Emerg Infect Dis (1999) 5:607. doi:10.3201/eid0505.990502

4. Smith HW, Tucker JF. The effect of antibiotic therapy on the faecal excretion of Salmonella Typhimurium by experimentally infected chickens. J Hyg (1975) 75:275-92. doi:10.1017/S0022172400047306

5. Manning JG, Hargis BM, Hinton A Jr, Corrier DE, DeLoach JR, Creger CR. Effect of nitrofurazone or novobiocin on Salmonella Enteritidis cecal colonization and organ invasion in leghorn hens. Avian Dis (1992) 36(2):334-40. doi:10.2307/1591508

6. Piddock LJ, Wise R. Mechanisms of resistance to quinolones and clinical perspectives. J Antimicrob Chemother (1989) 23(4):475-80. doi:10.1093/ $\mathrm{jac} / 23.4 .475$

7. Acar JF, Goldstein FW. Trends in bacterial resistance to fluoroquinolones. Clin Infect Dis (1997) 24(Suppl 1):S67-73. doi:10.1093/clinids/24.Supplement_1. S67

8. Seuna E, Nurmi E. Therapeutical trials with antimicrobial agents and cultured cecal microflora in Salmonella infantis infections in chickens. Poult Sci (1979) 58(5):1171-4. doi:10.3382/ps.0581171

9. Niewold TA. The nonantibiotic anti-inflammatory effect of antimicrobial growth promoters, the real mode of action? A hypothesis. Poult Sci (2007) 86(4):605-9. doi:10.1093/ps/86.4.605

10. Morales-Barrera E, Calhoun N, Lobato-Tapia JL, Lucca V, Prado-Rebolledo O, Hernandez-Velasco X, et al. Risks involved in the use of enrofloxacin for Salmonella Enteritidis or Salmonella Heidelberg in commercial poultry. Front Vet Sci (2016) 3:72. doi:10.3389/fvets.2016.00072

11. Bartlett JG. Clinical practice. Antibiotic-associated diarrhea. N Engl J Med (2002) 346(5):334-9. doi:10.1056/NEJMcp011603 modulating the intestinal microflora. The idea is more applicable now than ever since bacterial antimicrobial resistance has become a serious worldwide problem both in medical and agricultural fields. It looks like finally, we humans have learned that this is a lost war against bacterial pathogens, especially, if we keep abusing of antibiotics. Bacteria are equipped with the biological mechanisms to evolve and find mechanisms of resistance against any chemical. Hence, antibiotic alternatives such as probiotics, prebiotics, phytochemicals, enzymes, organic acids, and vaccines to improve disease resistance in highly intense/stress food animal production systems have become a priority for many scientists around the world $(36,37)$. Evidently, there is no such thing as a silver bullet. Rather, the combination of several of these nutraceuticals, accompanied with good husbandry and management practices, oriented to improve biosecurity programs are becoming the new strategies incorporated in many companies. In this research topic, we present 10 original research articles and 1 general commentary article included in 5 different chapters, evaluating multiple alternatives to antibiotic growth promoters to be used in animal production.

\section{AUTHOR CONTRIBUTIONS}

All authors listed have made a substantial, direct, and intellectual contribution to the work and approved it for publication.

12. Van Der Wielen PW, Biesterveld S, Notermans S, Hofstra S, Urlings BA, van Knapen F. Role of volatile fatty acids in development of the cecal microflora in broiler chickens during growth. Appl Environ Microbiol (2000) 66:2536-40. doi:10.1128/AEM.66.6.2536-2540.2000

13. Corrier DE, Hinton A Jr, Ziprin RL, Beier RC, DeLoach JR. Effect of dietary lactose on cecal $\mathrm{pH}$, bacteriostatic volatile fatty acids, and Salmonella Typhimurium colonization of broiler chicks. Avian Dis (1990) 34(3):617-25. doi: $10.2307 / 1591254$

14. Bronstein JL, Alarcón R, Geber M. The evolution of plant-insect mutualisms. New Phytol (2006) 172:412-28. doi:10.1111/j.1469-8137.2006.01864.x

15. Kikuchi Y, Hosokawa T, Nikoh N, Meng XY, Kamagata Y, Fukatsu T. Host-symbiont co-speciation and reductive genome evolution in gut symbiotic bacteria of acanthosomatid stinkbugs. BMC Biol (2009) 7:2. doi:10.1186/1741-7007-7-2

16. Saridaki A, Bourtzis K. Wolbachia: more than just a bug in insects genitals. Curr Opin Microbiol (2010) 13:67-72. doi:10.1016/j.mib.2009.11.005

17. Neish AS. Microbes in gastrointestinal health and disease. Gastroenterology (2009) 136:65-80. doi:10.1053/j.gastro.2008.10.080

18. Martin R, Nauta AJ, Ben Amor K, Knippels LM, Knol J, Garssen J. Early life: gut microbiota and immune development in infancy. Benef Microbes (2010) 1:367-82. doi:10.3920/BM2010.0027

19. Duerkop BA, Vaishnava S, Hooper LV. Immune responses to the microbiota at the intestinal mucosal surface. Immunity (2009) 31:368-76. doi:10.1016/j. immuni.2009.08.009

20. Moran NA. Symbiosis as an adaptive process and source of phenotypic complexity. Proc Natl Acad Sci U S A (2007) 104:8627-33. doi:10.1073/ pnas.0611659104

21. Tlaskalová-Hogenová H, Stěpánková R, Kozáková H, Hudcovic T, Vannucci L, Tučková $\mathrm{L}$, et al. The role of gut microbiota (commensal bacteria) and the mucosal barrier in the pathogenesis of inflammatory and autoimmune diseases and cancer: contribution of germ-free and gnotobiotic animal models of human diseases. Cell Mol Immunol (2011) 8:110-20. doi:10.1038/cmi.2010.67

22. Walter J, Britton RA, Roos S. Host-microbial symbiosis in the vertebrate gastrointestinal tract and the Lactobacillus reuteri paradigm. Proc Natl Acad Sci U S A (2011) 108:4645-52. doi:10.1073/pnas.1000099107 
23. Bäckhed F. Programming of host metabolism by the gut microbiota. Ann Nutr Metab (2011) 58:44-52. doi:10.1159/000328042

24. Choct M. Managing gut health through nutrition. Br Poult Sci (2009) 50:9-15. doi:10.1080/00071660802538632

25. Murray BE. Resistance of Shigella, Salmonella, and other selected enteric pathogens to antimicrobial agents. Rev Infect Dis (1986) 8:S172-81. doi:10.1093/clinids/8.Supplement_2.S172

26. Uwaydah AK, Matar I, Chacko KC, Davidson JC. The emergence of antimicrobial resistant Salmonella typhi in Qatar: epidemiology and therapeutic implications. Trans R Soc Trop Med Hyg (1991) 85:790-2. doi:10.1016/ 0035-9203(91)90457-A

27. Griggs DJ, Hall MC, Jin YF, Piddock LJ. Quinolone resistance in veterinary isolates of Salmonella. J Antimicrob Chemother (1994) 33:1173-89. doi:10.1093/ jac/33.6.1173

28. Couper MR. Strategies for the rational use of antimicrobials. Clin Infect Dis (1997) 24:S154-6. doi:10.1093/clinids/24.Supplement_1.S154

29. Rodrigue DC, Tauxe RV, Rowe B. International increase in Salmonella Enteritidis: a new pandemic? Epidemiol Infect (1990) 105:21-7. doi:10.1017/ S0950268800047609

30. Randall LP, Cooles SW, Coldham NC, Stapleton KS, Piddock LJ, Woodward MJ. Modification of enrofloxacin treatment regimens for poultry experimentally infected with Salmonella enterica serovar Typhimurium DT104 to minimize selection of resistance. Antimicrob Agents Chemother (2006) 50:4030-7. doi:10.1128/AAC.00525-06

31. Castanon JI. History of the use of antibiotic as growth promoters in European poultry feeds. Poult Sci (2007) 86:2466-71. doi:10.3382/ps.2007-00249

32. Hofer E, dos Reis EMF. Salmonella serovars in food poisoning episodes recorded in Brazil from 1982 to 1991. Rev Inst Med Trop Sao Paulo (1994) 36:7-9. doi:10.1590/S0036-46651994000100002
33. Irino K, Fernandes SA, Tavechio AT, Neves BC, Dias AM. Progression of Salmonella Enteritidis phage type 4 strains in São Paulo State, Brazil. Rev Inst Med Trop Sao Paulo (1996) 38:193-6. doi:10.1590/S0036-46651996000 300005

34. Borsoi A, Santin E, Santos LR, Salle CT, Moraes HL, Nascimento VP. Inoculation of newly hatched broiler chicks with two Brazilian isolates of Salmonella Heidelberg strains with different virulence gene profiles, antimicrobial resistance, and pulsed field gel electrophoresis patterns to intestinal changes evaluation. Poult Sci (2009) 88:750-8. doi:10.3382/ps.200800466

35. Metchnikoff E. The Prolongation of Life: Optimistic Studies. Broadway, NY: Springer (1907).

36. Subbiah MT. Nutrigenetics and nutraceuticals: the next wave riding on personalized medicine. Transl Res (2007) 149:55-61. doi:10.1016/j.trsl.2006. 09.003

37. Hailu G, Boecker A, Henson S, Cranfield J. Consumer valuation of functional foods and nutraceuticals in Canada. A conjoint study using probiotics. Appetite (2009) 52:257-65. doi:10.1016/j.appet.2008.10.002

Conflict of Interest Statement: The authors declare that the research was conducted in the absence of any commercial or financial relationships that could be construed as a potential conflict of interest.

Copyright $\odot 2017$ Tellez and Latorre. This is an open-access article distributed under the terms of the Creative Commons Attribution License (CC BY). The use, distribution or reproduction in other forums is permitted, provided the original author $(s)$ or licensor are credited and that the original publication in this journal is cited, in accordance with accepted academic practice. No use, distribution or reproduction is permitted which does not comply with these terms. 